\title{
Traditions and Innovations of Educational Activity and Pedagogical Process (From the History of Public Education in Crimea)
}

\author{
Nataliia Vasilievna Kriukova ${ }^{1, *}$, Elena Viktorovna Novikova ${ }^{1}$, Victoriia \\ Vladimirovna Mironenko ${ }^{1}$, Elena Lvovna Zelinskaya ${ }^{2}$, Gennadii Ivanovich \\ Makarenko $^{3}$
}

\author{
1 Department of social and humanitarian disciplines, V.I. Vernadsky Crimean Federal University (Sevastopol \\ Economics and Humanities Institute (Branch)), Sevastopol, Russia \\ ${ }^{2}$ Department of management, V.I. Vernadsky Crimean Federal University (Sevastopol Economics and Humanities \\ Institute (Branch)), Sevastopol, Russia \\ ${ }^{3}$ Department of law, V.I. Vernadsky Crimean Federal University (Sevastopol Economics and Humanities Institute \\ (Branch)), Sevastopol, Russia \\ * Corresponding author. Email: nkrjukowa1969@mail.ru
}

\begin{abstract}
The study reveals the concept of "innovation in education" and also justifies the need for innovative changes in modern education at the international, state and regional levels based on the above documents and legislative acts. A comprehensive analysis of printed and archival sources revealed the main directions of development of educational activities and the pedagogical process in Crimea in a historical retrospective. Particular attention is paid to the study of the educational activities of pedagogical collectives of the oldest educational institutions, the formation of a vocational education system, the role of outstanding teachers in the development of the educational space of the region.
\end{abstract}

Keywords: education, pedagogical process, innovations, students, teachers, Crimea

\section{INTRODUCTION}

The study of educational activities and the pedagogical process are relevant in modern science, attracting the attention of philosophy and history, pedagogy and methodology. The study of these phenomena at the moment is of particular importance when the educational system in the world and in the Russian Federation undergoes changes and transformations in accordance with the requirements of the time. However, despite this, the development of the educational process and pedagogical activity at the regional level in the context of traditions and innovations is not sufficiently studied. In this regard, the novelty of this study lies in the fact that trends in the development of the educational process in the world and in Crimea were established on the basis of analysis of archival documents and printed sources, state legislative acts and international documents (introduction of innovations, taking into account the territorial factor in the organization of vocational training) .

\section{METHODOLOGY}

A. N. Dzhurinsky [1], T.G. Kiseleva [2], D.I. Latyshina [3] and others considered this problem from a historical point of view. Philosophical and methodological grounds are presented in the works of K.S. Pigrov [4], V.A. Bordovsky [5], V.S. Lazarev [6] and other authors. Works S.A. Pisareva [7], N.N. Surtaeva [8] and other researchers are devoted to innovation in pedagogical activity at present. Foreign experience in studying innovative technologies in education is presented in publications of many authors, for example, Ludwig J. Issing and Heike Schaumburg [9], Kevin Kinser [10].

In this study, historical-genetic, comparative methods, as well as methods of system analysis were used.

\section{RESULTS AND DISCUSSION}

The creation of the new is advisable when it does not destroy the old, the traditional, but enhances and develops the historical heritage, taking into account the new 
sociocultural realities. Features in the educational spaces of the regions cannot be ignored by reforming the entire system of modern education. Therefore, the study of certain aspects of the educational process in the regions of the country, namely, in Crimea, is particularly interesting. It should be noted that the formation of the state system of public education in Crimea began, as throughout the Russian Empire, at the end of the 18th century. At this time, the peninsula was incorporated into Russia and the process of its integration into the all-Russian space began. The Tauride region was transformed into a province with seven counties in 1802. Evpatoria, Perekop, Simferopol, Feodosia, Yalta counties were located within the peninsula. Sevastopol and Kerch-Yenikalsk city administrations were also allocated on the territory of Crimea. The northern districts of Berdyansk, Dnieper, Melitopol were on the mainland.

The educational activities of the teaching staff of educational institutions of Crimea can be represented on the basis of the analysis of archival documents and the corpus of printed sources. According to the fund of the Directorate of Public Schools of the Tauride Province of the State Archive of the Republic of Crimea, the first congress of public teachers of the Tauride Province was held in early summer 1869 in Simferopol; the congress was organized on the initiative and at the expense of the Zemstvo authorities [11]. The congress was led by Ilya Petrovich Derkachev, a teacher at the Simferopol men's treasury gymnasium, as well as a publicist, children's writer and public figure [12]. The teacher believed that improving the activities of primary and secondary schools would be effective provided that they systematically study their experience and traditions, use their own textbooks and teaching aids in the educational process, and also if there is a scientifically based organizational and methodological system of training personnel for work at school, taking into account national-religious and territorial-regional conditions of Crimea. The study of archival documents and little-known literary sources, scientific and journalistic works, textbooks of the second half of the 19th century indicate that modern problems in the primary and secondary education industry are similar to those that were solved by the pedagogical community of that period, including I.P. Derkachev [13]. Humanistic ideas of I.P. Derkachev is further developed in the theory and practice of modern school: ensuring close connection of schooling with the life experience of the student, individualization of instruction, the use of various forms and types of creative activity of students in the educational process, labor education as an important aspect of their spiritual development [14].

In addition, the history of educational activities in Crimea, a valuable historical source is the minutes of meetings of pedagogical collectives of educational institutions in the region. An analysis of the protocols shows that teachers very often discussed the problem of providing quality training. To achieve this, pedagogical councils have repeatedly considered the implementation of programs in subjects. The trustee of the Odessa educational district invited teachers to discuss the programs of the Ministry of Education. He asked teachers to present "their thoughts on how these programs serve the interests of students" [15]. In the $70-80$ s of the 19th century, teachers of educational institutions of Crimea proposed their own program for studying a particular subject at the meetings of the teacher's council. Some changes in the curriculum at the beginning of the 20th century prompted teachers of Crimea to devote several meetings of pedagogical councils to the question of "the results of a partial transformation of the educational system of the secondary school, admitted in the form of experience with the highest resolution" [16]. Teachers noted that most of all children showed interest in the study of natural history and history.

The teaching staff of educational institutions of Crimea was interested in how students absorbed the knowledge gained. Teachers paid great attention to the quality of knowledge, made every effort to ensure that "possibly more developed and knowledgeable people" graduated from secondary schools [17]. To this end, the teaching staff showed tireless concern for the quality of education. This was expressed in a constant analysis of student performance (on average, the quality of knowledge was $40-70 \%$ in general, $50-90 \%$ in individual subjects). Teachers carefully analyzed the reasons for the drop-in student performance since the 70 s of the 19th century.

Since the beginning of the 20th century, success tables have been used to evaluate student learning outcomes in subjects. The main task of teachers was to develop "a habit of work as the basis of well-being in the subsequent life, and therefore the school should serve as an example of hard work" [18].

The teacher's speeches played a special role in the lesson, because "a living expressive word acts, ignites the spirit of a person" [19]. Many protocols of pedagogical councils emphasize that the teacher must possess not only knowledge, but "and the ability to transmit it, as well as require knowledge from students" [20].

It should be noted that teachers paid considerable attention to ensuring that homework was thought out and not overload students. Each educational institution solved the problem of overloading students with educational material in their own way. For example, the teachers' council at the Yevpatoriya male gymnasium decided that teachers should not give written work in all classes on Mondays. The director of the Sevastopol Konstantinovsky school was concerned about the overload of students and demanded that homework in class I be no more than 1 hour, in class II - 1.5, and in class VII - no more than 4.5 hours [18].

"Works on literature, history and ancient languages should intersect and test knowledge in several subjects" to facilitate students' homework [21]. Compositions were checked by teachers of various subjects.

Teachers used various forms of working with students to deepen knowledge in subjects. Most often these were 
literary conversations, disputes, which took place 2 times a month. Such evenings contributed not only to instilling interest in subjects, but also formed the ability to conduct a discussion, correctly express their thoughts and defend their point of view.

The most important indicator of the quality of knowledge, the correct use of certain methodological techniques was the success of students, both current and in trials at the end of the school year. The minutes of the meetings of pedagogical councils of various educational institutions of Crimea contain detailed information about the annual learning outcomes. Grades "5" are very few, which indicates the difficulty of learning and a certain severity. In general, analyzing the surviving protocols, we can conclude about a very responsible approach of teaching staff to the level of education of their students.

The pedagogical team considered its task to be the education of a highly moral person who owns the skills of a culture of behavior. At meetings of teachers' councils, teachers analyzed student behavior.

Since the 19th century, considerable attention has been paid to the practical training of specialists for new branches of the economy introduced in the region in the Crimean counties of the Tauride province. Not only the Ministry of Education, but also other relevant departments were interested in creating such professional educational institutions. In the Tauride province, such professional educational institutions included:

1. Agricultural educational institutions. The most famous of them, who made a significant contribution to the development of agriculture in the region, include the Crimean Viticulture School, established in Sudak in 1804 [22]; Magarach School of Horticulture and Winemaking, opened in 1828 at the Crimean Imperial Botanical Garden; The Livadia Imperial School (founded in 1876), in which, in addition to general subjects, students were given craft education with a bias in agriculture; lower agricultural school of the 1st category, a school of garden workers in the estate "Salgirka", a gardening school at the Simferopol shelter for juvenile delinquents [23].

2. Vocational schools. The Sevastopol Craft School of the Russian Society of Steamboats and Commerce under the Admiralty, opened in 1866, can be attributed to the most famous ones [24]. The Kerch Craft School, which was founded in 1884 at the expense of the city society, was also very famous in Crimea.

3. Nautical schools. Already at the beginning of the 19th century, a naval school was opened in Sevastopol by the Maritime Department to educate children of sailors in the volume of an elementary school [25]. The so-called seafaring classes began to be created for the needs of the merchant fleet by a special decision of the government by the maritime department since 1867; In total, six were opened and they were transferred to the Ministry of Finance at the end of the 19th century. In the learning process, special attention was paid to the practical training of students, which they took on ships at sea [26]. In 1903-
1905, the seafaring classes were transformed into naval colleges.

4. Female teacher training institutions. For example, the most famous institutions for the training of teachers by the end of the 19th century were the Simferopol Tatar teacher's school, the German central school, and the Feodosia teacher's institute. From the end of the 19th century, women's professional schools were also created. By the beginning of the 20th century, there were five such schools, most of which were classified as private. Girls in them were taught needlework, sewing, cutting, knitting.

Thus, in the 19th - early 20th centuries there was an extensive network of professional educational institutions in the Crimean counties of the Tauride province, which trained specialists, mainly of the lower and middle categories for many sectors of culture and economy.

The prevailing Soviet education system has preserved some aspects of the pedagogical process of the prerevolutionary school: continuity in education, class-lesson system, exams at the end of the year, etc. However, it should be noted that educational activity was largely subject to the ideological dictatorship of the system as a whole.

In the late 20th - early 21 th centuries, the institutional core of the education system undergoes a change in the context of globalization through the implementation of modernization transformations. In the past, a mass school that implements a class-lesson system and a unified curriculum was this basis; Today, the core of the educational system is the individual educational program of the student, which he can master not only within the walls of the educational institution, but also outside it, using multiple means of communication. The priority task of education is the formation of a comprehensively developed, creative personality, able to cope with extraordinary modern problems. The solution to this problem lies primarily in the use of an innovative learning strategy.

There is a document of international scale "Kronberg Declaration on the Future of the Process of Acquisition and Transfer of Knowledge", developed by a group of experts gathered at the invitation of UNESCO and the German Commission for UNESCO on June 22-23, 2007 in Kronberg (Germany).

The declaration states that

- the process of creation, acquisition and transfer of knowledge has undergone significant changes due to the rapid development of new information and communication technologies and the social transformations caused by them;

- new approaches are required to bridge the gap in the level of knowledge in different parts of the world, while ensuring cultural and linguistic diversity;

- the Internet and new educational technologies provide everyone with many opportunities;

- it is necessary to constantly adapt new technologies and processes in order to develop human-oriented and development-oriented, inclusive knowledge societies [27]. 
The document does not diminish the role of the "classical model of acquiring knowledge, including teachers / mentors working within the framework of this model" [27]; however, the document emphasizes that "the processes of acquiring and transferring knowledge in the next twenty-five years will increasingly be mediated by technological advances (that is, be carried out online), so traditional educational processes will undergo revolutionary changes and new knowledge societies will arise" [27].

In other words, innovation in education is the production and use of a new intellectual product by mastering the socially significant experience of mankind in order to obtain conscious benefits for innovation subjects. In this regard, the philosophical understanding of the innovative process in education is interesting. According to the philosopher K.S. Pigrov, "innovation is in a complex, contradictory relationship with the social institution of education" [4]. The institution of education is conservative in nature and translated knowledge must be stable to a certain extent, because it is difficult to transmit "unstable" knowledge, especially if the teacher does not believe that such knowledge will remain "forever" [4]. This is the complexity of innovative processes, because it is necessary to overcome the inertia inherent in society as a whole and the educational system in particular.

However, innovative activity in education is declared at the state level. Article 20 of the Federal Law "On Education in the Russian Federation", entitled "Experimental and innovative activity in the field of education" states that "Experimental and innovative activity in the field of education is carried out in order to ensure the modernization and development of the educational system, taking into account the main directions of socio-economic development of the Russian Federation, the implementation of priority areas of the state policy of the Russian Federation in the field of education" [28]. "Innovation activity is focused on improving scientific, pedagogical, educational, methodological, organizational, legal, financial, economic, human, material and technical support of the education system and is carried out in the form of implementation of innovative projects and programs by organizations engaged in educational activities and other existing in the field of education organizations, as well as their associations" [28].

Currently, innovative research activities in the Republic of Crimea are carried out in educational institutions of 12 municipalities and 34 innovative projects are implemented on the basis of the Order of the Ministry of Education, Science and Youth of the Republic of Crimea dated October 9, 2017 N 2499 "On approval of regional innovation platforms engaged in educational activities Republic of Crimea" [29].

\section{CONCLUSION}

It was found that special attention was paid to such problems as the implementation of curricula in subjects, quality control of knowledge, student overload, as a result of analysis of archival documents and printed sources, namely, minutes of meetings of pedagogical collectives of educational institutions in the region, indicating the characteristics of the organization of educational activities and pedagogical process in the territory of Crimea in the second half of the 19th - early 20th centuries. The regional factor was taken into account when organizing vocational education (agricultural educational institutions, nautical schools). It should be assumed that innovations were also characteristic of the educational process in the studied period, for example, the introduction of their own programs for studying a particular subject. The latter testifies to the laws of development of all education and regional education in particular: innovative changes are inevitable, since the content of education, teaching methods must meet the requirements of the times.

Thus, we can conclude that the transformations currently taking place in the world and society as a whole (globalization, the informatization of society), imply inevitable changes in education in general, and in the educational systems of individual states, as well as regions in particular. The study of development trends of modern pedagogical technologies and specific innovative projects in Crimea can serve as material for further study.

\section{REFERENCES}

[1] A.N. Dzhurinsky, The history of education and pedagogical thought, Vlados-Press, 2003.

[2] T.G. Kiseleva, Public education and enlightenment in Russia: reality and myths, MGUKI, 2002.

[3] D.I. Latyshina, The history of pedagogy: upbringing and education in Russia (10th - early 11th century), Forum, 1998.

[4] K.S. Pigrov, Innovation and education, in: Conference proceedings, Symposium Series, issue 29, Saint Petersburg, Saint Petersburg Philosophical Society, 2003, pp. 11-15.

[5] V.A. Bordovsky, Innovation processes in the modern system of higher pedagogical education, Publishing House of The Herzen State Pedagogical University of Russia, 2001.

[6] V.S. Lazarev, Pedagogical innovation: object, subject and basic concepts, Pedagogy 4 (2004) 11-21. 
[7] S.A. Pisareva, A.P. Tryapitsyna, Non-linearity of the educational process in higher education, in: Scientific schools of the Institute of Pedagogy: collection of articles of the Third All-Russian pedagogical (Herzen) readings, Saint Petersburg, April 18, 2019, The Herzen State Pedagogical University of Russia, Institute of Pedagogy, pp. 61-66.

[8] N.N. Surtaeva, Problems and trends in the development of pedagogical activity in vocational education, in: Problems of pedagogical innovation in vocational education: Materials of the $19^{\text {th }}$ International Scientific and Practical Conference, Saint Petersburg, Publishing House of The Herzen State Pedagogical University of Russia, 2018, pp. 21-26.

[9] Ludwig J. Issing, Heike Schaumburg, Educational technology as a key to educational innovation: state of the art report from Germany, Tech Trends 45(6) (2001) 23-28.

[10] Kevin Kinser, Innovation in higher education: a case study of the western Governors University new directions for higher education 137 (2007).

[11] The State Archive of the Autonomous Republic of Crimea. F. 100. Op. 1. D. 1353. 1. 5.

[12] I.P. Derkachev, The first congress of teachers in the city of Simferopol, Teacher 17 (1869) 549-558.

[13] I.P. Derkachev, Zemsky schools, Novorossiysk Telegraph 4 (1872) 89-91.

[14] I.P. Derkachev, Thoughts on public education, Russian Speech 4 (1861) 124-127.

[15] The State Archive of the Autonomous Republic of Crimea. F. 104. Op. 1. D. 1866.

[16] The State Archive of the Autonomous Republic of Crimea. F. 546. Op. 1. D. 22.

[17] The State Archive of the Autonomous Republic of Crimea. F. 104. Op. 1. D. 258.

[18] Archive of the city of Sevastopol. F. 26. Op. 1. D. 1.

[19] The State Archive of the Autonomous Republic of Crimea. F. 624. Op. 1. D. 2.

[20] The State Archive of the Autonomous Republic of Crimea. F. 104. Op. 1. D. 1078.
[21] The State Archive of the Autonomous Republic of Crimea. F. 100. Op. 1. D. 1377.

[22] The State Archive of the Autonomous Republic of Crimea. F. 26. Op. 1. D. 5211. 1. 375.

[23] Directory of the Tauride province for 1911, Simferopol, 1911, p. 38.

[24] The State Archive of the Autonomous Republic of Crimea. F. 100. Op. 1. D. 1723.1. 2.

[25] The State Archive of the Autonomous Republic of Crimea. F.100. Op. 1. D. 694.1. 58, 60.

[26] Review of the situation of public education in 1908-1911, Simferopol, 1911, p. 58.

[27] E. Altovsky, Kronberg Declaration on the Future of the Process of Acquisition and Transfer of Knowledge, Higher Education Today 9 (2007) 74-75.

[28] Federal Law of December 29, 2012, No 273 (as amended on 01.03.2020) "On Education in the Russian Federation", Collection of legislation of the Russian Federation of December 31, 2012, No 53 (part I), Art. 7598.

[29] Order of the Ministry of Education, Science and Youth of the Republic of Crimea dated October 9, 2017, No 2499 "On the approval of regional innovation platforms operating in the field of education of the Republic of Crimea", Available at: https://monm.rk.gov.ru/file/pr2499-09102017.PDF. 